\title{
DIAGNOSTIC APPLICATIONS OF INFRARED THERMOGRAPHY IN CAPTIVE BRAZILIAN CANIDS AND FELIDS
}

\author{
(Aplicações diagnósticas da termografia infravermelha em canídeos e felídeos \\ brasileiros em cativeiro)
}

\author{
André Luiz Mota da Costa ${ }^{1}$, Fabrício Braga Rassy ${ }^{2}$, João Batista da Cruz ${ }^{3}$ \\ 'Zoológico de Sorocaba, Sorocaba, São Paulo, Brasil, ${ }^{2}$ Fundação Parque Zoológico de São Paulo, \\ São Paulo, São Paulo, Brasil, ${ }^{3}$ Universidade Federal de São Carlos, São Carlos, São Paulo, Brasil \\ Corresponding author: almotacosta@yahoo.com.br
}

\begin{abstract}
Infrared thermography is a noninvasive diagnostic imaging method that does not require animal restraint. This tool provides instant images in real time, even at great distances, being very advantageous for wild animals. The thermograph measures the frequency of infrared rays, it locates hot or cold regions in the body tissues, detecting physiological or pathological processes that modify body temperature. In the veterinary diagnosis of wild animals, thermal imaging is used to determine lesions, inflammation and the anatomical location that causes lameness. It also can be used to diagnosis infectious diseases, reproductive period or gestation and to measure animal welfare and stress levels. This research aimed to use infrared thermography as a tool for remote diagnosis in Brazilian canids and felids kept ex-situ at the Sorocaba Zoo, Brazil. During one year the images were recorded biweekly in 42 individuals (18 canids and 24 felids). No thermal change was noticed in the images taken biweekly. Twelve animals presented symptoms at different times, then images were taken immediately and recorded every 3 days to follow the evolution of the clinical signs and treatment. Atypical images were interpreted and correlated with the clinical signs. The method showed good sensitivity all over the body when applied to felids. In the canids there was good sensitivity for head and limb disorders, because these regions have shorter hair. It is concluded that thermography is an important diagnostic tool for canids and felids, being an examination carried out at a distance, without stress, non-invasive and painless, prioritizing animal welfare.
\end{abstract}

Keywords: Animal welfare; carnivores; imaginology; zoo.

RESUMO: A termografia infravermelha é um método não invasivo de diagnóstico por imagem que não requer contenção dos animais. Essa ferramenta provê imagens instantâneas, em tempo real, a grandes distâncias, sendo muito vantajosa para animais selvagens. O termógrafo, aparelho que mede a frequência dos raios infravermelhos, localiza regiões quentes ou frias nos tecidos corpóreos, detectando processos fisiológicos ou patológicos que alterem a temperatura corporal. No diagnóstico veterinário de animais selvagens, a imagem térmica é usada para determinar lesões, inflamações e localização anatômica das claudicações; no diagnóstico de doenças infecciosas, período reprodutivo e gestação; e para avaliar o bem-estar animal e níveis de estresse. Essa pesquisa teve como objetivo utilizar a termografia infravermelha como ferramenta de diagnóstico em canídeos e felídeos selvagens ex-situ, no Zoológico de Sorocaba, Brasil. Durante um ano as imagens foram registradas quinzenalmente em 42 indivíduos, sendo 18 da Família Canidae e 24 da Família Felidae. Nenhuma alteração térmica foi notada nas imagens tomadas 
quinzenalmente. Doze animais apresentaram sintomas em momentos distintos, sendo então tomadas imagens imediatas e repetidas a cada três dias para acompanhar a evolução do quadro clínico e tratamento. Imagens atípicas foram interpretadas e correlacionadas com o quadro clínico. O método mostrou boa sensibilidade para felídeos em toda superfície corpórea. Nos canídeos houve boa sensibilidade para afecções de cabeça e membros, por serem regiões de pelame mais curto. Conclui-se que a termografia é uma importante técnica para canídeos e felídeos, auxiliando no diagnóstico ou norteando o veterinário em sua conduta; sendo ainda um exame realizado à distância, sem estresse, não invasivo e indolor, priorizando o bem-estar animal.

Palavras-chave: Bem-estar animal; carnívoros; imaginologia; zoológico. 


\section{INTRODUCTION}

The "Brazil Red Book of Threatened Species of Fauna" classifies four of the six species of Brazilian canids as vulnerable and all of the eight species of Brazilian felids are at risk (Ministério do Meio Ambiente, 2016). Habitat loss, conflicts with humans and hunting are the main factors for population decline (Ramos Junior et al., 2003; Brown, 2011). Zoos around the world have great interest in the conservation of these species (Oliveira; Cassaro, 1999). The development of an efficient technique for remote diagnosis can minimize stress and collaborate on conservation projects (Teixeira et al., 2017).

Infrared (IR) thermography is the technique of non-invasive inspection, performed with the use of an infrared system for the measurement of temperatures or observation of differential patterns of heat distribution, in order to provide information regarding to an operational condition of a component, equipment or process. Infrared is an electromagnetic frequency naturally emitted by any body, but that frequency is beyond human vision. The equipment that identifies and measures this frequency is an IR camera or scanner; that becomes extremely easy to locate hot or cold regions by interpreting the thermograms that provide images in temperature ranges (Matias, 2002).

The IR camera converts infrared radiation into electrical impulses, which are converted into digital values. Thus an easily interpreted image can be analyzed through the software (Sanches, 2009). These programs can use multicolored or monochrome grayscale images. When the image is multicolored, it has been standardized that colors in shades of blue and purple indicate that the temperature is low, while colors in warmer tones, ranging from red to yellow, indicate a higher temperature (Lahiri et al., 2012).
The heat generated during the inflammatory process is transferred to adjacent tissues (including the dermis) by an increased blood flow; consequently there is energy dissipation that is easily identified by the IR camera. Thus, physiological or pathological processes involving change in body surface temperature can be evaluated by this technique (Bowers et al., 2009).

Infrared thermography is a noninvasive diagnostic imaging tool that does not require patient manipulation or restraint. This method provides instant images in real time, even at great distances. It shows images of the whole body of the animal and can be compared with other animals of the group, also allowing examination in movement. (Hilsberg-Merz, 2008). Thermograms do not require external illumination or irradiation of the object and can be obtained in total darkness. They are not influenced by skin color or pigmentation, as they depend solely and directly on skin temperature (Purohit et al., 1977). The technique is best applied on short-haired animals, since the long hairs can cause thermal isolation of the body and make difficult the interpretation of the images. Hilsberg-Merz (2008) mentions that in mammals of the Order Carnivora there is this difficulty related with the long hair.

Thermography has the great advantage of being early in detecting problems in some cases (Mikail, 2010). In equine medicine it is possible to identify a lesion that causes claudication until two weeks before symptoms (Strömberg, 1973; Vaden et al., 1980; Marr, 1992). It is an examination of high sensitivity, but of low specificity, and should be used in conjunction with other imaging modalities such as ultrasonography, radiography or computed tomography (Infernuso et al., 2010). 
Eulenberger and Kämpfer (1994) were the first to recommend the use of IR thermography in wildlife medicine, both in-situ or ex-situ. Philips (1992) was the first to perform large-scale thermoregulation studies with zoo animals, using IR thermography. However, the equipment used was not practical for field situations, whether in zoos or in the field. In another study Hilsberg-Merz (2000) was the first to use a modern IR camera in wildlife medicine.

In the veterinary diagnosis of wild animals, IR thermography is used to determine the causes of lameness, lesions, and inflammation. It is also used in the diagnosis of infectious diseases, reproductive period and gestation; and to control animal welfare and stress levels (Cilulko et al., 2013). Research on animals kept in zoos is scarce, being important references two researches carried out on birds (Hurley-Sanders et al., 2012; Duncan et al., 2016), one with mustelids (Kuhn et al., 2009), two with elephants (Weissenböck et al., 2010; Rowe et al., 2013) and two with mammals in general (Hilsberg-Merz, 2000; Mortola, 2013).

Infrared thermography was used to detect temperature changes in mule deer (Odocoileus hemionus) infected with foot-and-mouth disease virus. A considerable increase in temperature was detected by the IR camera two days before the animals presented the symptoms (Dunbar et al., 2009). In another study, IR termography was used to diagnose sarcoptic mange in freeliving Spanish ibex (Capra pyrenaica) and had its use compared to distance evaluation through binoculars (Arenas et al., 2002). In raccoons (Procyon lotor) IR termography was used to detect rabies virus infection before the animals showed clinical signs of the disease, based on the nasal temperature gradients (Dunbar; McCarthy, 2006). In a jaguar (Panthera onca) IR thermography indicated a large hyperthermic area in the abdomen and subsequently cytological and histopathological exams accounted for a malignant neoplasm (Teixeira et al., 2017).

Infrared thermography was tested in wild canids and felids exploring the potential of the technique for remote diagnosis in these species kept in captivity. The goals of the present study were: correlate the images and clinical findings, using this tool as a complementary examination in imaginology, with no need for restraint; evaluate what types of diseases can be diagnosed with IR thermography in Brazilian canids and felids; evaluate if IR thermography may indicate image changes before the symptoms and monitor the evolution of clinical treatment remotely.

\section{MATERIALS AND METHODS}

The present work was developed at the Sorocaba Zoo, State of São Paulo, Brazil. Three species of canids and seven species of felids were studied in this research, totalizing 42 adult animals (Table 1).

The apparatus used to capture the images was the FLIR thermograph, model T460. The power source for the operation of this camera is a rechargeable battery. This thermograph is extremely lightweight and portable, making it easy to carry and handle, being ideal for field work. The images are archived on a hard disk inside the camera and then transferred to the software where the images are evaluated. The color pattern used in this research was the "silver", with images in grey scales, where the darker shades indicate lower temperatures, while lighter shades indicate higher temperatures. By visualizing a heterogeneous pattern of colors in some area of the body, points are fixed in this region to establish (in degrees Celsius) 
the temperature of dots with different shades. These temperatures are compared with those of adjacent areas, contralateral areas and with the same region at other times. Thus we know if the image keeps the pattern previously recorded or if it is atypical. With this classification of the image we correlate with the clinical picture and verify if the images are consistent or not with the symptomatology.

Table 1 - Species, number of individuals and gender (M-Male; F-Female).

\begin{tabular}{|c|c|c|c|}
\hline Common name & Scientific name & Gender $\left(\mathbf{M}^{1} / \mathbf{F}^{2}\right)$ & Total \\
\hline Canids & & $10 / 8$ & 18 \\
\hline Crab-eating fox & Cerdocyon thous & $3 / 2$ & 5 \\
\hline Maned wolf & Chrysocyon brachyurus & $5 / 3$ & 8 \\
\hline Hoary fox & Pseudalopex vetulus & $2 / 3$ & 5 \\
\hline Felids & & $14 / 13$ & 27 \\
\hline Northern tiger cat & Leopardus tigrinus & $4 / 1$ & 5 \\
\hline Margay & Leopardus wiedii & $2 / 4$ & 6 \\
\hline Jaguarundi & Herpailurus yagouaroundi & $2 / 2$ & 4 \\
\hline Pampas cat & Leopardus colocolo & $1 / 0$ & 1 \\
\hline Ocelot & Leopardus pardalis & $2 / 0$ & 2 \\
\hline Jaguar & Panthera onca & $1 / 2$ & 3 \\
\hline Puma & Puma concolor & $1 / 2$ & 3 \\
\hline NUMBER OF INDIVIDUALS & & $23 / 19$ & 42 \\
\hline
\end{tabular}

The distance of the thermograph to the animal was established considering the possibility of approach of each species and the spatial characteristic of the enclosure, without stress to the animal and with safety to the camera operator (Table 2). The distance was determined by a measuring tape.

The period studied was from August 1, 2016 to July 31, 2017, totaling twelve months and covering all seasons of the year, only during the day. Images were taken biweekly in all 42 specimens. However, when one of the animals had symptoms, the images were immediately recorded in this individual and later we started to take images of this specimen every three days until remission of symptoms. Thus, image capture returns to its biweekly frequency at the end of treatment.

Table 2 - Distance between $\mathrm{IR}^{1}$ camera and animal.

\begin{tabular}{lc}
\hline Species & Distance (meters) \\
\hline \multicolumn{1}{c}{ Canids } & 1,5 \\
Cerdocyon thous & 4,0 \\
Pseudalopex vetulus & \\
Chrysocyon brachyurus & \\
$\quad$ Felids & \\
Herpailurus yagouaroundi & \\
Leopardus colocolo & 1,5 \\
Leopardus pardalis & \\
Leopardus tigrinus & \\
Leopardus wiedii & \\
Panthera onca & 4,0 \\
Puma concolor & \\
Tinfrared &
\end{tabular}




\section{RESULTS AND DISCUSSION}

During the study no atypical images were noticed in the biweekly records. Twelve animals presented symptoms at different times (six animals of the Canidae Family and six animals of the Felidae Family). These clinical cases are described in Table 3 and detailed in items 1 to 12 .

The list is organized (Table 3) according to the chronological order of the cases, indicating the disease involved in each case. "YES" is written for those in which the thermal images were atypical and "NO" for those that the thermal images maintained the standard.
1. Panthera onca, male, microchip 0001DB-7888. Atypical image: YES

It was an elderly jaguar that presented a sudden swollen in the right inguinal region and it was possible to detect temperature increase in this site (Figure 1). The jaguar was anesthetized for evaluation and a firm tumor measuring $25,0 \mathrm{~cm}$ in length was detected. Aspirative cytology indicated malignant mesenchymal tumor. After the surgical removal fibrosarcoma was confirmed with histopathological analysis. Thermographic follow-up of the healing and surgical site was performed for one year, with no alterations in the image or in the clinical signs.

Table 3 - List of twelve clinical cases with identification (microchip number), gender, disease and presence of atypical image.

\begin{tabular}{cccccc}
\hline Case & Species & Microchip & Gender & Disease & Atypical \\
\hline 1 & Panthera onca & 7888 & $\mathrm{M}^{1}$ & Neoplasm & YES \\
2 & Cerdocyon thous & 39820 & $\mathrm{~F}^{2}$ & Trauma & YES \\
3 & Leopardus pardalis & 23089 & $\mathrm{M}^{1}$ & Pododermatitis & NO \\
4 & Herpailurus yagouaroundi & 23490 & $\mathrm{~F}^{2}$ & Psychogenic & YES \\
& Herpailurus yagouaroundi & 39727 & $\mathrm{M}^{1}$ & Psychogenic & YES \\
5 & Leopardus tigrinus & 22305 & $\mathrm{M}^{1}$ & Periodontitis & YES \\
6 & Chrysocyon brachyurus & 3685 & $\mathrm{M}^{1}$ & Osteoartrosis & NO \\
7 & Pseudalopex vetulus & 493331 & $\mathrm{~F}^{2}$ & Trauma & YES \\
8 & Cerdocyon thous & 3698 & $\mathrm{~F}^{2}$ & Trauma & YES \\
9 & Cerdocyon thous & 39519 & $\mathrm{M}^{1}$ & Trauma & YES \\
10 & Chrysocyon brachyurus & 872393 & $\mathrm{M}^{1}$ & Trauma & NO \\
11 & Leopardus tigrinus & 23660 & $\mathrm{M}^{1}$ & Renal disease & NO \\
12 & & & &
\end{tabular}

male, ${ }^{2}$ female

In this case hyperthermia was evidenced well delimited and circumscribed. The short hair of the species collaborated with the identification of the hyperthermic point, as soon as it was noticed the increase of volume (Figure 1), which was at least $2,2^{\circ} \mathrm{C}$ above adjacent tissues.

2. Cerdocyon thous, female, microchip 963007000039820. Atypical image: YES

The fox presented discomfort in the left ear. At the remote inspection no changes were observed due to the pelage. The thermographic image showed hyperthermia in relation to the right ear (Figure 2), with a difference of $3,3^{\circ} \mathrm{C}$ between them. After anesthesia an abscess was found in the ear and lesions compatible with bite.

After three days of treatment there was no discomfort, but there was still a thermal difference between the ears. After nine days, the image showed the ears with equal temperatures.

The ocelot presented licking at the extremity of the left thoracic limb. 
Images were recorded and there was no thermal difference between the plantar regions of the two thoracic limbs. Without atypical images in thermographic examination, the animal was anesthetized for physical examination. A fissure was seen in the foot pad, located $5,0 \mathrm{~mm}$ deep in

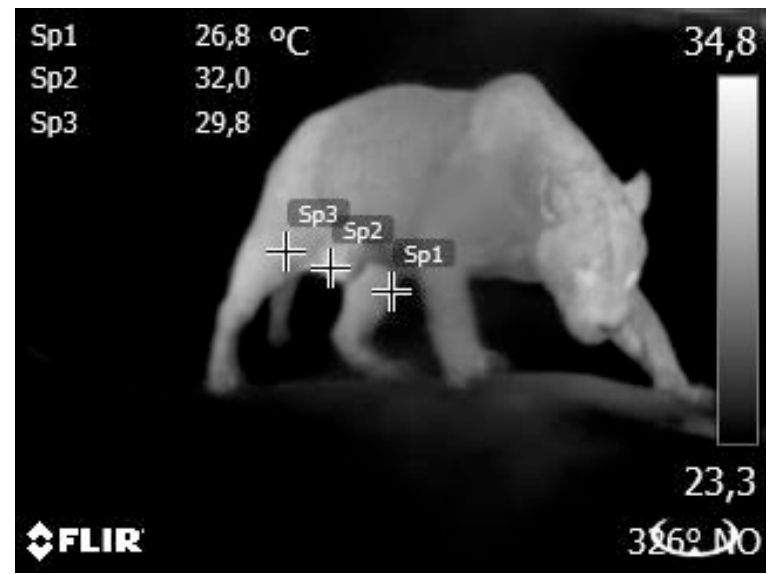

Figure 1. Thermal image of a jaguar (Panthera onca) - Sp2 is the point located in the swelling (inguinal region), indicating a temperature of $32,0^{\circ} \mathrm{C}$. Sp1 is the point located in the left knee $\left(26,8^{\circ} \mathrm{C}\right)$, being the most hypothermic. Sp3 is the point on the right leg $\left(29,8^{\circ} \mathrm{C}\right)$.

4. Herpailurus yagouaroundi, female, microchip 939000004023490. Atypical image: YES

The jaguarundi was with inguinal swollen and hair rarefaction evident at a distance. The thermographic image indicates an area that was $3,1^{\circ} \mathrm{C}$ above the temperature of the adjacent area. Animal was anesthetized and there was a large accumulation of fat in the inguinal region (obesity) and a cutaneous lesion characterized by broken hairs at the base, suggestive of excessive licking (psychogenic dermatitis). The higher temperature was due to the absence of local hair covering, which would provide thermal insulation. Full healing of the lesion was verified after two months and it was possible to follow the improvement with the IR termography. In this case, IR thermography proved to be very useful relation to its surface. After two days of treatment the animal was asymptomatic. None of the subsequent thermal images were atypical. The IR thermography in this case was not sensitive enough to detect the lesion.

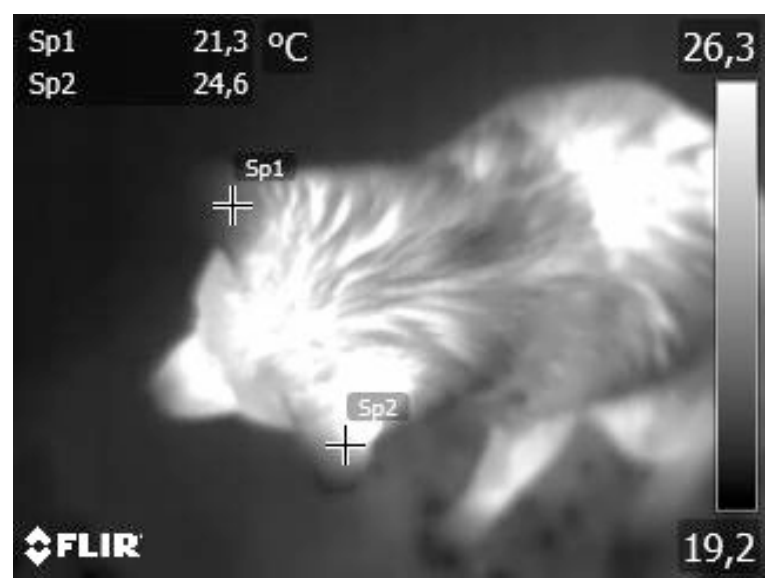

Figure 2. Thermal image of a crab-eating fox (Cerdocyon thous) - Right ear temperature is the point Sp1 $\left(21,3^{\circ} \mathrm{C}\right)$ and the left ear temperature is the point Sp2 $\left(24,6^{\circ} \mathrm{C}\right)$.

in the remote monitoring of cutaneous lesions, avoiding restraint and stress.

5. Herpailurus yagouaroundi, male, microchip 963007000039727. Atypical image: YES

The cat was with several areas of hair rarefaction in the trunk, on the same day that the animal of case 04 appeared with similar lesions (they were in the same enclosure). The thermal images indicated higher temperature in areas with hairs failure, probably due to the absence of thermal insulation. In this case it is probable that some factor outside the enclosure has stimulated excessive licking. At the thermographic follow-up of the lesions, complete repilation was observed after three months.

6. Leopardus tigrinus, male, microchip 939000004022305. Atypical image: YES 
The cat presented left infraorbital volume increase. There was an area of hair rarefaction and fistula draining purulent secretion. Thermal image indicated in the center of the lesion a hypothermic area and in the periphery showed a hyperthermic area. After anesthesia, it was concluded that the volume increase was an abscess due to a periodontal infection. The hypothermic area was due to necrotic cutaneous tissue and the hyperthermic area represented an adjacent inflammatory process. After fifteen days the animal had no external lesion or atypical thermographic image. In this case, we see the importance of IR thermography for the diagnosis of disorders that lead to reduced blood flow or areas of necrosis, which are characterized by hypothermic points.

7. Chrysocyon brachyurus, male, microchip 963008000003685. Atypical image: NO

This maned wolf had difficulty getting up and presented lameness in the pelvic limbs. Thermographic image showed no difference between temperatures measured in limbs, thoracic spine and lumbar spine. The patient was anesthetized and radiographic examination revealed ventral osteophytes between the ninth thoracic vertebra and the tenth thoracic vertebra (characteristic of osteoarthrosis). The wolf was treated with carprofen for five days and showed no further symptoms. In this case, the IR thermography was not able to accuse change in the thermal pattern due to the long hair of the trunk.

8. Lycalopex vetulus, female, microchip 956000000493331. Atypical image: YES

The fox presented excessive licking on the right thoracic limb. Thermal imaging detected only one hyperthermic spot on the right elbow. With an anesthetized animal, bite punctured lesions were visualized. In addition to the lesion detected by thermography, there was an injury to the medial side of the limb. After nine days of treatment the animal was asymptomatic and without hyperthermia in the images.

9. Cerdocyon thous, female, microchip 963008000003698. Atypical image: YES

This animal presented lameness in the left thoracic limb. The thermographic image shows hyperthermic point. After anesthesia, only local edema was detected. The radiographic evaluation indicates obliquous fissure in the distal third of the left ulna, with preservation of the bone alignment. Carprofen treatment was performed and no immobilization was required. After three days new image was taken registering lower temperature in the place and the patient was asymptomatic.

10. Cerdocyon thous, male, microchip 963007000039519. Atypical image: YES

The fox presented lameness in the right thoracic limb. The thermal image of the phalangeal region showed hyperthermia in relation to the carpus. The patient was anesthetized and a complete phalangeal fracture was found on the radiographic exam. Carprofen treatment was performed and no immobilization was required. After six days, it was asymptomatic and had no hyperthermic spots.

11. Chrysocyon brachyurus, male, microchip 985111000872393. Atypical image: NO

The maned wolf was with claudication in the left thoracic limb. The thermal images were not atypical. It was anesthetized for clinical and radiographic evaluation. Nothing was detected in the exams. The patient was medicated with carprofen and on the sixth day was asymptomatic. In this case, the thermal images were not atypical, despite the obvious lameness of the left thoracic limb. The diagnostic hypothesis is a muscular contusion, an 
injury difficult to detect with an anesthetized animal and in the radiographic images.

\section{Leopardus tigrinus, male, microchip} 939000004023660. Atypical image: NO

The cat was found in extreme apathy in the enclosure, without presenting previous symptoms. Thermal images were within the standard. The cat was anesthetized for evaluation. The patient received fluid therapy and died after one hour. Biochemical tests showed high levels of urea $(847 \mathrm{mg} / \mathrm{dL}-$ maximum value $50 \mathrm{mg} / \mathrm{dL}$ ) and creatinine $(11,0 \mathrm{mg} / \mathrm{dL}$ - maximum value $2,0 \mathrm{mg} / \mathrm{dL}$ ) (Silva; Adania, 2006). Necropsy indicated bilateral renal fibrosis with severe architectural alteration, confirming that the renal failure was the cause of death. The thermal images maintained the pattern, because even with the animal in shock the rectal temperature was $38,0^{\circ} \mathrm{C}$. In this case we did not expect atypical images in a normothermic patient.

\section{General discussion}

There were no findings in the images that were performed following the main methodology of this study. In the twelve cases, the symptoms were prior to the detection of the alterations of the images. Several authors mention that it is possible to detect atypical thermal images (with points of hypo or hyperthermia), before the symptoms (Mikail, 2010). This was not the case for this research, probably for the interval between the images being of fifteen days. In the researches reported in domestic animals the samplings are more frequent, facilitating the detection of thermal changes prior to the symptoms (Strömberg, 1973; Vaden et al., 1980; Marr, 1992).

In four cases where IR thermography did not detect atypical images, there were explanations for all of them. In case 03, it would be unlikely that the IR camera detected hyperthermia in $5,0 \mathrm{~mm}$ depth of the footpad, a tissue that has the characteristic of being very irrigated. In case 07 , due to the long and thick hair on the back, the thermal insulation is great, making it difficult to capture the infrared rays emanated by the region (maned wolf with osteoarthrosis). In short-haired dogs, this same type of lesion is easily detected by IR thermography (Grossbard et al., 2014). Some authors have already reported the difficulty related to the long hair; but Hilsberg-Merz (2008) is still more specific, citing that in longer-haired animals such as the Carnivora Order, the interpretation of results is more difficult. However, it can not be generalized that this technique is less recommended for the Carnivora Order, since in short-haired animals of the Felidae family it was very promising and in longer-haired animals (such as the Brazilian canids) the technique showed effective sensitivity in the head and limbs. In case 11 , the hypothesis is a contusion of a deeper muscle group, since in the physical evaluation and in the radiography nothing was detected, as in IR thermography. In case 12 , of renal failure, an atypical thermal image is not expected.

In general, in this research, infrared thermography was an examination of high sensitivity, but of low specificity, as already mentioned by some authors (Infernuso et al., 2010); and should be associated with other imaging modalities or other complementary exams. Its relevance in the wild animal medicine is the aid to the veterinary conduct, assisting the veterinarian in the decisions that involve handling, restraint, diagnosis and therapeutics.

It is worth emphasizing the need for more studies with this technique, mainly in relation to the standardization of images and mapping of some species, which can serve as a 
parameter for others with taxonomic similarities, encouraging the use of infrared thermography in wild animal medicine and conservation, both ex-situ and in-situ.

\section{CONCLUSIONS}

It is possible to correlate the images with the observed symptoms, being a good complementary exam, dispensing any type of conditioning, restraint or sedation. The IR thermography has good sensitivity to diagnose conditions in Brazilian felids. However, in Brazilian canids, it shows low sensitivity in affections that affect the trunk (thorax and abdomen) and shows good sensitivity for affections of limbs and head. In this study, infrared thermography was not able to detect atypical thermal images prior to clinical symptomatology, using a biweekly record of images. It was possible to monitor the evolution of clinical treatment remotely, thus avoiding frequent restraint and stress of the animals, showing to be highly favorable to the maintenance of animal welfare.

\section{ACKNOWLEDGMENTS}

We thank the Post-Graduate Program in Wildlife Conservation, a joint initiative of the Federal University of São Carlos and the São Paulo Zoological Park Foundation.

\section{REFERENCES}

ARENAS, A.; GOMEZ, F.; SALAS, R. et al. An evaluation of the application of infrared thermal imaging to the telediagnosis of sarcoptic mange in the Spanish ibex (Capra pyrenaica). Veterinary Parasitology, v.109, p. 111117, 2002.

BOWERS, S.; GANDY, S.; ANDERSON, $B$ et al, S. Assessment of pregnancy in the late-gestation mare digital infrared thermography. Theriogenology, vol. 72, p. 372-377, 2009.

BROWN, J.L. Female reproductive cycles of wild female felids. Animal Reproduction Science. v. 124, pp 155162, 2011.

CILULKO, J.; JANISZEWSKI, P.; BOGDASZEWSKI, $M$. et al. Infrared thermal imaging in studies of wild animals. European Journal of Wildlife Research, vol. 59, p. 17-23, 2013.

DUNBAR, M.R.; JOHNSON, S.R.; RHYAN, J.C. et al. Use of infrared thermography to detect thermographic changes in mule deer (Odocoileus hemionus) experimentally infected with foot-and-mouth disease. Journal of Zoo and Wildlife Medicine, vol. 40, p.296301, 2009.

DUNBAR, M.R.; MCARTHY, K.A. Use of infrared thermography to detect signs of rabies infection in raccoons (Procyon lotor). Journal of Zoo and Wildlife Medicine, vol. 37, n.4, p. 518-523, 2006.

DUNCAN, A.E.; TORGERSON-WHITE, L.L.; ALLARD, S.M. et al. An Evaluation of Infrared Thermography for Detection of Bumblefoot (pododermatitis) in Penguins. Journal of Zoo and Wildlife Medicine, 47(2), p. 474-485, 2016

EULENBERGER, K.; KÄMPFER, P. Infrared thermography in zoo and wild animals: first experiences (Die Infrarotthermografie bei Zoo- und Wildtieren: ErsteErfahrungen), Verhandlungsbericht des 36, International Symposium Erkrank Zoo Wildtiere, p. 181-183, 1994.

GROSSBARD, B.P.; LOUGHIN, C.A.; MARINO, D.J. et al. M.Medical Infrared Imaging (Thermography) of Type I Thoracolumbar Disk Disease in Chondrodystrophic Dogs. Veterinary Surgery, v.43, p. 869-876, 2014. 
HILSBERG-MERZ, S. Aspects of the clinical use of infrared thermography in zoo and wild animal medicine (Aspektezurklinischen Anwendung der Infrarot-Thermographie in der Zoo- und Wildtiermedizin), 2000, University of Leipzig (PhD dissertation).

HILSBERG-MERZ, S. Infrared Termography in Zoo and Wild Animals. In: FOWLER, M.E.; MILLER, R.E. Zoo and Wild Animal Current Therapy, Vol. 6, Saunders Elsevier, St. Louis, 2008. p. 20-33.

HURLEY-SANDERS, J. L.; BOWMAN, K.F.; WOLFE, B.A. et al. Use of Thermography and Fluorescein Angiography in the Management of a Chilean Flamingo With Avascular Necrosis of the Wing. Journal of Avian Medicine and Surgery, 26(4), p. 255257, 2012.

INFERNUSO, T.; LOUGHIN, C.A.; MARINO, D.J. et al. Thermal imaging of normal and cranial cruciate ligamentdeficient stifles in dogs. Veterinary Surgery, vol.39, n.4, p.410-417, 2010.

KUHN, R.A.; MEYER, W. Infrared thermography of the body surface in the Eurasian otter Lutra lutra and the giant otter Pteronura brasiliensis. Aquatic Biology, vol.6, p. 143-152, 2009.

LAHIRI, B.B.; BAGAVATHIAPPAN, S.; JAYAKUMAR, T. Medical application of infrared thermography: A review. Infrared Physics \& Technology, vol.55, n.4, p.221- 235, 2012.

MARR, C.M. Microwave thermography: a non-invasive technique for investigation of injury of the superficial digital flexor tendon in the horse, Equine Veterinary Journal. vol. 24, n.4, p. 269-273, 1992.

MATIAS, J. Mecatrônica Atual. Ano 1, n³. São Paulo. Saber Ltda. 2002. p. 36.

MIKAIL, S. Termografia: diagnóstico através da temperatura. Nosso Clínico, vol.13, n.74, p.20-24, 2010.
MINISTÉRIO DO MEIO AMBIENTE. Brazil Red Book of Threatened Species of Fauna. INSTITUTO CHICO MENDES DE CONSERVAÇÃO DA BIODIVERSIDADE - ICMBio. p. 16-17, 2016.

MORTOLA, J.P. Thermographic Analysis of Body Surface Temperature of Mammals. Zoological Science, vol. 30(2), p. 118-124, 2013.

OLIVEIRA, T.G.; CASSARO, K. Guia de identificação dos Felinos Brasileiros. $2^{a}$ edição. Sociedade de Zoológicos do Brasil, São Paulo, 1999. 60 p.

PHILLIPS, P.K. Regulation of surface temperature in mammals, UrbanaChampaign, 1992, University of Chicago (PhD dissertation).

PUROHIT, R. C. et al. Value of clinical thermography in veterinary medicine. Auburn Veterinarian, vol.33, n.3, p.104-108, 1977.

RAMOS JUNIOR, V.A.; PESSUTTI, C.; CHIEREGATTO, C.A.F.S. Guia de Identificação dos Canídeos Silvestres Brasileiros. Formato digital, JoyJoy Studio Ltda., Sorocaba, 2003. 35 p.

ROWE, M.F.; BAKKEN, G.S.; RATLIFF, J.J. et al. Heat storage in Asian elephants during submaximal exercise: behavioral regulation of thermoregulatory constraints on activity in endothermic gigantotherms. The Journal of Experimental Biology, vol. 216, p. 1774-1785, 2013.

SANCHES, I. J. Sobreposição de imagens de termografia e ressonância magnética: uma nova modalidade de imagem médica tridimensional. 2009. 168p. Tese (Doutorado em Engenharia Elétrica e Informática Industrial) - Universidade Tecnológica Federal do Paraná, Curitiba, 2009.

SILVA, J.C.R.; ADANIA, C.H. Cap. 31Carnivora - Felidae (Onça, Suçuarana, Jaguatirica, Gato-do-mato). In: CUBAS, 
Z.S.; SILVA, J.C.R.; CATÃO-DIAS, J.L. Tratado de Animais Selvagens Medicina Veterinária, Ed. Roca, São Paulo, 2006. p. 505-546.

STRÖMBERG, B. Morphologic, thermographic and ${ }^{133} \mathrm{Xe}$ clearance studies on normal and diseased superficial digital flexor tendons in race horses, Equine Veterinary Journal, v.5, pp. 156-161, 1973.

TEIXEIRA, R. H. F.; COSTA, A. L. M.; MUROLLO, N.D. et al. Fibrossarcoma em onça-pintada (Panthera onca): uso da termografia associada à citologia aspirativa como auxílio diagnóstico. Clínica Veterinária, vol. 22, p. 72-78, 2017.

VADEN, M.F.; PUROHIT, R.C.; McCOY, M.D. et al. Thermography: a technique for subclinical diagnosis of osteoarthritis, American Journal of Veterinary Research, vol. 41, p. 1175-1180, 1980.

WEISSENBÖCK, N.M.; WEISS, C.M.; SCHWAMMER, H.M.; et al. Thermal windows on the body surface of African elephants (Loxodonta africana) studied by infrared thermography. Journal of Thermal Biology, vol. 35, p. 182-188, 2010. 